\title{
Agrobacterium tumefaciens-transient genetic transformation of Habanero pepper (Capsicum chinense Jacq.) leaf explants
}

\author{
Guadalupe Fabiola Arcos-Ortega \\ Centro de Investigaciones Biológicas del Noroeste \\ Col. Playa Palo de Santa Rita \\ La Paz, B.C.S., México
}

Rafael Antonio Chan-Kuuk

Instituto Tecnológico Superior de Calkiní Calkiní, Campeche, México

Wilma Aracely González-Kantún

Unidad de Bioquímica y Biología Molecular de Plantas

Centro de Investigación Científica de Yucatán Col. Chuburná de Hidalgo Mérida, Yucatán, México

\section{Ramón Souza-Perera}

Unidad de Bioquímica y Biología Molecular de Plantas

Centro de Investigación Científica de Yucatán

Col. Chuburná de Hidalgo

Mérida, Yucatán, México

\section{Yumi Elena Nakazawa-Ueji}

Unidad de Bioquímica y Biología Molecular de Plantas

Centro de Investigación Científica de Yucatán

Col. Chuburná de Hidalgo

Mérida, Yucatán, México

\section{Elidé Avilés-Berzunza}

Unidad de Bioquímica y Biología Molecular de Plantas

Centro de Investigación Científica de Yucatán

Col. Chuburná de Hidalgo

Mérida, Yucatán, México

\section{Gregorio Godoy-Hernández}

Unidad de Bioquímica y Biología Molecular de Plantas

Centro de Investigación Científica de Yucatán

Col. Chuburná de Hidalgo

Mérida, Yucatán, México

\section{Michael A. Lawton}

Biotechnological Center for the Agriculture and the Environment Cook College

Rutgers, The State University of New Jersey

New Brunswick, NJ, USA

José Juan Zúñiga Aguilar*

Unidad de Bioquímica y Biología Molecular de Plantas

Centro de Investigación Científica de Yucatán

Col. Chuburná de Hidalgo

Mérida, Yucatán, México

E-mail: zuniga_cicy@hotmail.com

Financial support: This work was funded by the Consejo Nacional de Ciencia y Tecnología (Project P48831).

Keywords: cocultivation, GUS assay.

*Corresponding author 
Most of the pepper species of the genus Capsicum have been recalcitrant to efficient Agrobacterium tumefaciens-mediated stable or transient, genetic transformation. In the present work, we optimized a protocol for transient transformation of the Habanero pepper (Capsicum chinense Jacq.) through the standardization of several experimental factors. These included the age of the plants, the temperature, the length of co-cultivation, the application of a negative (vacuum) and/or a positive (infiltration) pressure, along with micro injection, the use of acetosyringone during the bacterial culturing, and modification of the $\mathrm{pH}$ during the GUS assay to eliminate the endogenous $\beta$ glucuronidase activity. The standardized protocol, which yielded nearly $55 \%$ fully transformed leaf explants, was used to successfully mobilize two empty binary vectors (pCAMBIA2301 and pCAMex), as well as the $C$. chinense cDNAs encoding the pathogenesisrelated protein 10 and esterase, respectively.

In the last decade, Agrobacterium tumefaciens-mediated stable genetic transformation has been successfully performed with several members of the Solanaceae family (Ochoa-Alejo and Ramirez-Malagon, 2001; Nianiou et al. 2002). However, the genus Capsicum has remained largely recalcitrant to stable transformation and as a result only a low frequency and reproducibility ( $0.5-1 \%$ success rate) of transformation has been successfully achieved (Manoharan et al. 1998; Kim et al. 2001b; Li et al. 2003; Lee et al. 2004). The lack of a suitable pepper regeneration system represents a significant obstacle for its genetic manipulation and for the development of functional genomic studies (Ochoa-Alejo and Ramirez-Malagon, 2001; Shivegowda et al. 2002; Li et al. 2003; Lee et al. 2004). To overcome these difficulties, analyses of the gene functions of the pepper have been performed in heterologous systems; in the recent years the heterologous systems of Arabidopsis thaliana (Hong and Hwang, 2006), Solanum lycopersicum (Sarowar et al. 2006), Nicotiana tabacum (Park et al. 2006), and Allium cepa (Hong and Kim, 2005) have been used. However, a homologous transformation system to evaluate gene function is still needed for Capsicum.

Transient genetic transformation could be a valuable tool and offer a rapid assessment of gene function prior to stable transformation. By using transient genetic transformation, which is a relatively fast process that would require only 58 days from infiltration to gene expression, transformation may occur at high frequencies (Fischer et al. 1999; Van der Hoorn et al. 2000) and as result a large number of constructs may be tested (Kapila et al. 1997). In recent studies, Santana-Buzzy et al. (2005) and Zapata-Castillo et al. (2007) were able to regenerate shoots from the leafderived callus of the Habanero pepper. Thus, the transient transformation of Habanero pepper explants might also be exploited to attempt the stable transformation of pepper via organogenesis. In the present study, we assessed several factors to optimize an A. tumefaciens-mediated transient transformation protocol for Habanero pepper leaf explants.
The protocol was successfully used to mobilize the fullcDNAs of the genes encoding the pathogenesis-related protein 10 (EMBL AJ879115) and esterase (EMBL AJ879119), which were cloned from a $C$. chinense cDNA library constructed expressly from Phytophthora capsicielicited cell suspensions.

\section{MATERIALS AND METHODS}

\section{Biological materials and binary vectors}

Aseptically produced Habanero pepper plantlets of the "naranja" variety (Seminis ${ }^{\circledR}$ ) were used as the source of explants. The pepper seeds were surface sterilized by immersion in $70 \%(\mathrm{v} / \mathrm{v})$ ethanol for $5 \mathrm{~min}$, rinsed twice in sterile distilled water and again in a $30 \%(\mathrm{v} / \mathrm{v})$ solution of commercial chlorine (Cloralex ${ }^{\circledR}, 6 \%$ active chlorine) for 15 min with constant stirring. Then the seeds were thoroughly rinsed four times with sterile distilled water, and placed on sterile filter paper to eliminate an excess of water. The seeds were then preconditioned by spending five days at 25 $\pm 2^{\circ} \mathrm{C}$, in darkness, on Petri dishes of MS medium (Murashige and Skoog, 1962) supplemented with 3\% sucrose, $0.2 \%(\mathrm{v} / \mathrm{v})$ of Gelrite ${ }^{\circledR}$, without growth regulators and at a $\mathrm{pH}$ of 5.6. Finally, the seeds were transferred to a $16 \mathrm{hrs}$ photoperiod (photon flux density of $40-60 \mu \mathrm{mol} \cdot \mathrm{m}^{-}$ ${ }^{2} \cdot \mathrm{s}^{-1}$, provided by $39 \mathrm{~W}$ fluorescent lamps, Phillips, USA) at $25 \pm 2^{\circ} \mathrm{C}$. Upon completion of germination, the plantlets were transferred to magenta containers to wait until they were ready for transformation.

Agrobacterium tumefaciens strain LBA4404, either disarmed or transformed with empty or recombinant binary vectors (pCAMBIA2301/pCAMex or pCAMex::PR10/pCAMex::Esterase, respectively) were used for co-cultivation. The pCAMex binary vector was constructed by mobilizing the $35 \mathrm{~S}$ promoter and the OCS terminator sequences, derived from the pART7 plasmid (Gleave, 1992), into the multiple cloning site of the pCAMBIA1303 binary vector (http://www.cambia.org.au) (Figure 1). pCAMex::PR10 and pCAMex::Esterase were constructed by sub-cloning the corresponding full complementary DNAs encoding the pathogenesis-related 10 (PR10) and esterase proteins, from pTriplEx2 (Clontech, Palo Alto, Cal.), into the pCAMex plasmid digested with Kpn I and Xba I.

Wild-type and recombinant $A$. tumefaciens strains were cultured as described by Zaldivar-Cruz et al. (2003). In short, single colonies from each bacterial strain were inoculated into $50-\mathrm{mL}$ Erlenmeyer flasks containing $25 \mathrm{~mL}$ liquid YEB medium with $100 \mathrm{mg} \cdot \mathrm{L}^{-1}$ rifampicin, $100 \mathrm{mg} \cdot \mathrm{L}^{-}$ ${ }^{1}$ streptomycin, and either $50 \mathrm{mg} \cdot \mathrm{L}^{-1}$ kanamycin (sulphate salt, Sigma, St. Louis, Mo.) or, when needed, $50 \mathrm{mg} \cdot \mathrm{L}^{-1}$ hygromycin, all at a $\mathrm{pH}$ 5.6. The bacterial cultures were incubated in the presence or absence of acetosyringone (AS, 3'5'-Dimeth-oxy-4'-hydroxyacetophenone) for $24 \mathrm{hrs}$ at $28^{\circ} \mathrm{C}$ on a shaker that was adjusted to $200 \mathrm{rpm}$, until an O.D. $600 \mathrm{~nm}$ of 0.6 (late log phase) was reached. 

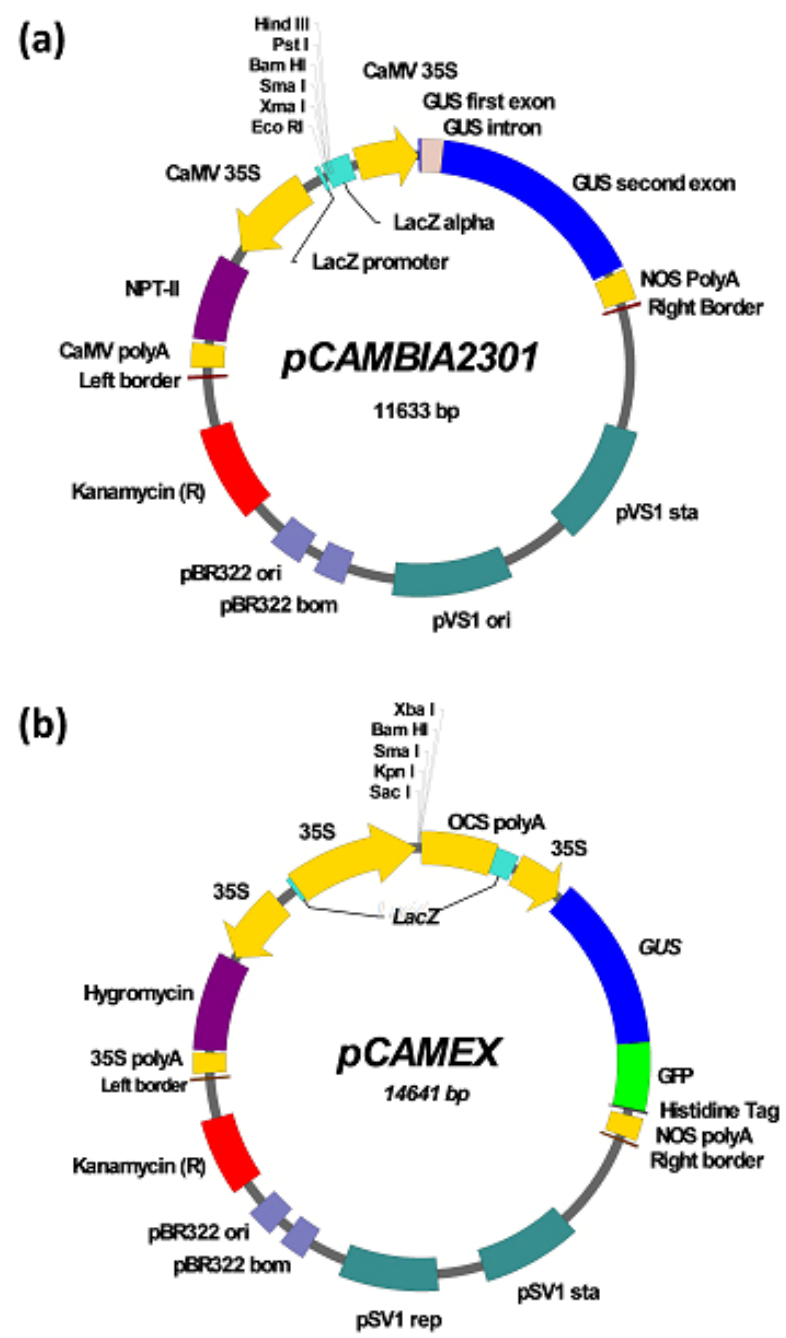

Figure 1. Binary vectors. A schematic representation of the binary vectors employed in this work as the negative controls, (a) pCAMBIA2301; (b) pCAMex, a binary vector constructed to over-express the inserts under the control of the $35 \mathrm{~S}$ promoter.

\section{Plant transformation}

At different periods following germination $(2,4,6$ and 8 weeks), the plantlets were aseptically pre-incubated for different periods of time $(0,1,2,6,12$ and $24 \mathrm{hrs})$ in liquid MS media without growth regulators. Then, the $A$. tumefaciens strains were infiltrated into the leaves by different methods: (1) The Vacuum method [V]: the leaves were submerged into the bacterial suspensions and a negative pressure (-1 atm.) was applied for $15 \mathrm{~min}$; (2) The Infiltration method [I]: the plantlets and the bacterial suspensions were poured into a $5-\mathrm{mL}$ syringe, then a positive pressure $(+1 \mathrm{~atm}$.) was applied for $5 \mathrm{~min}$; (3) The Micro-injection method [M]: the bacterial solutions were infiltrated directly, with a needleless syringe, into different points on the down-side of the leaves; (4) A combination of
$\mathrm{V}$ and I; (5) A combination of V and M; (6) A combination of I and $\mathrm{M}$; (7) A combination of $\mathrm{M}$ and I, then V. Following infiltration, each individual explant was rinsed with sterile MS medium and the co-cultivation was left in the dark for different periods of time (1,2 and 3 days) at either 20 or $28^{\circ} \mathrm{C}$. After co-cultivation, the leaf explants were washed thoroughly with sterile liquid MS medium and subsequently rinsed four times with $250 \mathrm{mg} \cdot \mathrm{L}^{-1}$ Cefotaxime (Claforan). Sixty leaf explants were used for each treatment.

\section{Analysis of transformed plants}

The efficiency of transient transformation was evaluated by the histochemical $\beta$-glucoronidase assay, and then by RTPCR amplification of the transgene transcripts. The leaf and hypocotyl explants were immersed in X-Gluc solution, consisting of $2 \mathrm{mM} \mathrm{X}$-Gluc (5-bromo-4-chloro-3-indolyl-bD-glucoronide), $100 \mathrm{mM}$ Tris- $\mathrm{HCl} \mathrm{pH} 8.0,50 \mathrm{mM} \mathrm{NaCl}, 2$ $\mathrm{mM}$ potassium ferricyanide, and 1\% (W/V) Triton X-100. After $12 \mathrm{hrs}$ incubation at $37^{\circ} \mathrm{C}$ in the dark, the explants were immersed in $70 \%$ ethanol until the chlorophyll had been completely bleached. Then, the explants were photographed under a light microscope. According to our requirements, only the explants displaying blue colour in the whole leaf area were considered to be GUS positive. In order to eliminate any possible endogenous GUS activity, the histochemical GUS assay was previously performed in non-transformed leaf explants with X-Gluc solutions and with different $\mathrm{pH}$ values (4.0, 7.0 and 8.0) (Alwen et al. 1992). All of the experiments were repeated three times.

For the gene expression analysis, total RNA was isolated from the transformed leaves using the Trizol ${ }^{\circledR}$ reagent, according to the manufacturer's instructions (Invitrogen). RT-PCR was carried out under the standard conditions in a My-Cycler ${ }^{\circledR}$ apparatus (BIO-RAD), with an initial denaturing step at $94^{\circ} \mathrm{C}$ for $5 \mathrm{~min}$; cycling conditions were $94^{\circ} \mathrm{C}$ for $1 \mathrm{~min}, 45^{\circ} \mathrm{C}$ for $1 \mathrm{~min}, 72^{\circ} \mathrm{C}$ for $1 \mathrm{~min}$; with a final extension of $10 \mathrm{~min}$ at $72^{\circ} \mathrm{C}$. The amplified fragments were fractionated by gel electrophoresis on a $1 \%$ agarose gel, stained with $1 \mu \mathrm{g} \cdot \mathrm{mL}^{-1}$ ethidium bromide and visualized under UV light. Amplification of the different transcripts was completed with the following combination of primers. For the GUS transcript, forward (5'AAAGTGTGGGTCAATAAT- ${ }^{\prime}$ ) and reverse (5'AAGCCAGTAAAGTAGAAG-3') primers amplified a 593 bp fragment. For the PR10 transcript, forward (5'TAATGAGTCCACAGTCCCAGTTGC-3') and reverse (5'-CACCATTTAAGCATAGGCAGAAGG-3') primers amplified a $460 \mathrm{bp}$ fragment. For the esterase transcript, forward (5'-CTTCCTGCAGCTTACGACGATG -3') and reverse (5'- AGCTGCTGCCTTTGATGGTTC -3') primers amplified a $560 \mathrm{bp}$ fragment.

To estimate the difference between the different treatments, a one-way analysis of variance (ANOVA) was used and the means were compared using the Tukey's post hoc test. All of the data are reported as the mean \pm standard error. For all 


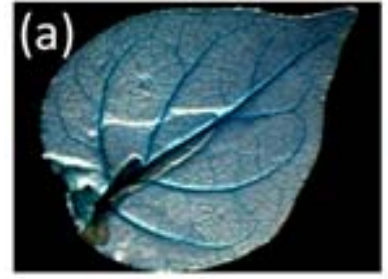

4.0

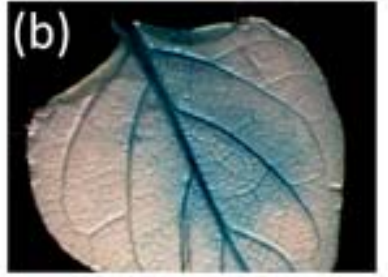

7.0

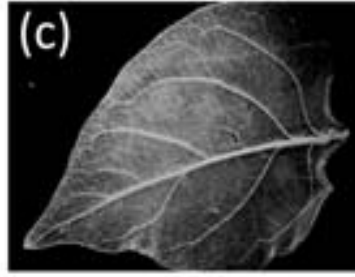

8.0
$\mathrm{pH}$

Figure 2. The effect of $\mathrm{pH}$ on endogenous $\beta$-glucuronidase activity in Capsicum chinense leaves. The non-transformed leaves of four-week-old plantlets were subjected to the GUS histochemical assay at different $\mathrm{pH}$ values. The leaves were blanched with successive ethanol washes and photographed under a light microscope. (a) $\mathrm{pH}$ 4.0; (b) $\mathrm{pH} 7.0$; (c) $\mathrm{pH}$ 8.0.

of the statistical analyses, the percentage results were transformed to arcsine before the ANOVA. The backtransformed means are presented and the standard errors are those obtained from the untransformed variables (Zar, 1999). The statistical significance was preset at $P<0.05$, although the $P$ values obtained are indicated. The statistical analyses were done with the General Linear Model (GLM) module with the Statistica software version 7.0 (StatSoft Inc., Tulsa OK, USA).

\section{RESULTS AND DISCUSSION}

In our lab, we analyze the interaction between Phytophthora capsici and the Habanero pepper at physiological, biochemical and molecular levels. Since one of our research goals is to study the dispersion of the oomycete mycelia through the leaf explants that are transformed with defence genes, we wanted to generate a transformation system that allows homogenous transgene expression through the whole leaf area, instead of having discrete transformation spots.

In this study, two types of binary vectors were used, pCAMBIA2301 and pCAMex (Figure 1). The first vector was used as a control to discriminate the false positives produced by the bacterial expression of transgenic GUS activity because this vector contains an intron in the reporter gene that cannot be processed by bacteria. Consequentially, the GUS staining is attributed to be exclusively from transformed plant tissues. pCAMex was constructed from pCAMBIA1303 (http://www.cambia.org) to constitutively express the genes of interest. pCAMex is a versatile binary vector that, in addition to the classic GUS histochemical detection assay, allows monitoring of the transformed tissues in vivo through detection of GFP in a light microscope.

(a)

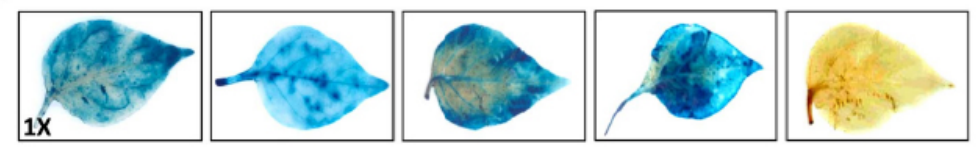

(b)
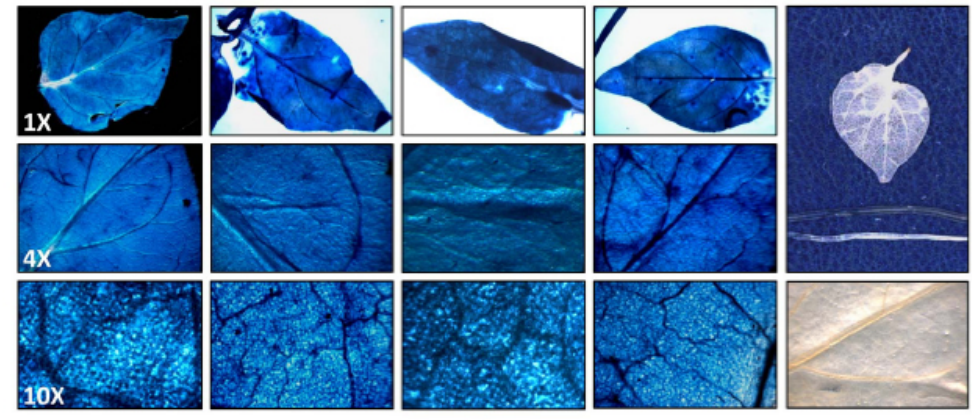

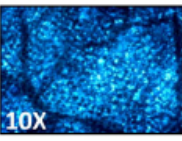

PCAMBIA2301

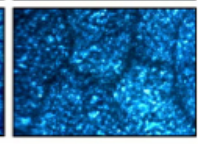

pCAMex::PR10

pCAMex::Esterase

disarmed LBA4404 strain

Figure 3. The effect of the explant age on the transformation efficiency. The leaf explants from the plantlets at different weeks after germination were transformed with the constructs indicated, under the optimal conditions referred to in the text. After the GUS histochemical assay, the leaves were blanched with successive ethanol washes and photographed at different zoom levels (1X, 4X and 10X) under a light microscope. (a) eight-week-old plantlets; (b) four-week-old plantlets. 
Table 1. The effect of different factors on the efficiency* of the transient transformation of Habanero pepper (Capsicum chinense) leaf explants. Data shown are Means \pm standard error of three independent experiments. The number of leaves utilized in each experiment was 60 .

\begin{tabular}{|c|c|c|c|c|c|c|}
\hline \multirow[t]{3}{*}{ Factors evaluated } & \multirow{3}{*}{$\begin{array}{l}\text { Treatment of each } \\
\text { factor }\end{array}$} & \multicolumn{4}{|c|}{ Number of Gus-positive leaf explants (percentage \pm standard deviation) } & \multirow[t]{3}{*}{ ANOVA } \\
\hline & & \multicolumn{4}{|c|}{ Constructs } & \\
\hline & & pCAMBIA2301 & pCAMex & pCAMex:PR10 & pCAMex:Est & \\
\hline \multirow{6}{*}{$\begin{array}{c}\text { Co-cultivation } \\
\text { conditions at dark } \\
\text { (days, temperature) }\end{array}$} & $3,20^{\circ} \mathrm{C}$ & 0 & 0 & 0 & 0 & \\
\hline & $2,20^{\circ} \mathrm{C}$ & 0 & 0 & 0 & 0 & \\
\hline & $1,20^{\circ} \mathrm{C}$ & 0 & 0 & 0 & 0 & $P<0.05$ \\
\hline & $3,28^{\circ} \mathrm{C}$ ** & $11(18.8 \pm 3.0)$ & $8(13.8 \pm 3.2)$ & $9(14.9 \pm 4.0)$ & $7(11.0 \pm 3.5)$ & \\
\hline & $2,28^{\circ} \mathrm{C}$ ** & $23(38.9 \pm 0.5)$ & $23(38.4 \pm 2.0)$ & $21(34.9 \pm 2.0)$ & $22(36.0 \pm 2.5)$ & \\
\hline & $1,28^{\circ} \mathrm{C}$ ** & $0^{\mathrm{a}}$ & 0 & 0 & 0 & \\
\hline \multirow{7}{*}{$\begin{array}{l}\text { Transformation } \\
\text { method }\end{array}$} & Vacuum (V) & 0 & 0 & 0 & 0 & \\
\hline & Infiltration (I) & $8(12.7 \pm 2.5)$ & $6(10.5 \pm 3.0)$ & $6(10.5 \pm 2.5)$ & $5(8.8 \pm 2.5)$ & \\
\hline & Micro-injection (M) & $03(4.9 \pm 2.6)$ & $05(8.3 \pm 3.0)$ & $02(3.8 \pm 2.0)$ & $04(6.6 \pm 3.6)$ & \\
\hline & $V+1$ & $12(20.0 \pm 3.0)$ & $10(16.6 \pm 4.0)$ & $8(12.7 \pm 4.1)$ & $6(10.5 \pm 4.0)$ & $P<0.05$ \\
\hline & $V+M$ & $04(7.2 \pm 2.0)$ & $06(9.4 \pm 2.5)$ & $03(5.5 \pm 3.0)$ & $05(8.8 \pm 3.0)$ & \\
\hline & I+M & $14(23.8 \pm 3.0)$ & $15(24.4 \pm 5.0)$ & $16(27.2 \pm 1.5)$ & $16(26.6 \pm 4.5)$ & \\
\hline & $M+I+V$ & $28(47.2 \pm 2.0)$ & $24(40.5 \pm 2.5)$ & $23(38.8 \pm 6.8)$ & $24(40.5 \pm 3.5)$ & \\
\hline \multirow{5}{*}{$\begin{array}{l}\text { Pre-incubation } \\
\text { period (hours) }\end{array}$} & 0 & $28(46.0 \pm 3.0)$ & $24(40.5 \pm 2.5)$ & $23(40.5 \pm 3.0)$ & $25(42.2 \pm 5.0)$ & \\
\hline & 1 & $42(69.4 \pm 5.0)$ & $40(67.1 \pm 2.5)$ & $43(71.6 \pm 5.5)$ & $40(67.1 \pm 2.5)$ & \\
\hline & 6 & $33(54.9 \pm 4.3)$ & $36(59.4 \pm 2.5)$ & $30(49.9 \pm 3.6)$ & $34(56.6 \pm 4.0)$ & $P<0.05$ \\
\hline & 12 & $40(66.6 \pm 2.0)$ & $33(54.4 \pm 4.7)$ & $32(53.8 \pm 2.0)$ & $35(58.3 \pm 3.6)$ & \\
\hline & 24 & $42(69.9 \pm 5.5)$ & $39(65.5 \pm 2.3)$ & $41(67.7 \pm 4.0)$ & $34(56.6 \pm 4.5)$ & \\
\hline
\end{tabular}

*Transient transformation efficiency was evaluated based on the number and percentages of GUS positive (GUS+) leaf explants produced. **On a shaker adjusted at and $200 \mathrm{rpm}$.

Values with a different superscript in the same column are significantly different $(P<0.05)$

Our first efforts to transform the Habanero pepper explants transiently, by vacuum infiltrating the bacterial solutions containing the binary vector controls, yielded no results at all; instead, the leaf explants showed a low level of GUS background activity, even in the negative controls. Since members of the Solanaceae family express an intrinsic $\beta$ glucuronidase activity (Plegt and Bino, 1989) that is dependent on the $\mathrm{pH}$ (Sudan et al. 2006), we assessed whether the endogenous activity in the Habanero pepper could be eliminated by modifying the $\mathrm{pH}$ of the histochemical assay (Alwen et al. 1992). We incubated the non-treated leaf explants with the GUS staining solution, buffered at different $\mathrm{pH}$ values. We found that incubation of the leaf explants at $\mathrm{pH} 4.0$ gave a widespread and weak staining that was especially prominent in the vascular

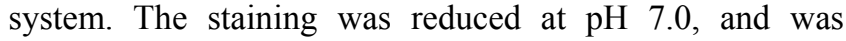
completely eliminated at $\mathrm{pH} 8.0$ (Figure 2). These results confirmed that the Habanero pepper, like other Solanaceae 
members, possesses an endogenous $\mathrm{pH}$-dependent $\beta$ glucuronidase activity. Therefore, the histochemical determinations for all of the transformation assays were done at $\mathrm{pH}$ 8.0.

Since using a direct application of the vacuum to infiltrate the bacterial solution gave no positive GUS results, we applied either a negative or positive pressure, or a combination of both pressures, in conjunction with a leaf puncture by a syringe needle in order to infiltrate the bacterial solutions. As can be observed in Table 1, a combination of the sequential application of a negative and positive pressure in the punched leaves gave the best results.

It has been demonstrated that the age of the plant can be a determinant for a tolerance against pathogenic microorganisms; the older the plant, the more tolerance they exhibit during an interaction with pathogens (Kim et al. 1989). In addition, several factors are critical for a successful transformation and these include the use of young seedling explants (Binns and Thomashow, 1988). Thus, we evaluated whether or not the age of the explants have had any influence over the transformation efficiency. As can be seen in Figure 3a-b and Figure 4a, the maximum efficiency of transient transformation with any of the constructs was reached when 4-week-old plantlets were used as source of explants; with 8-week-old plantlets and older, the transformation efficiency was compromised and serious tissue necrosis occurred in the explants, although non-homogenous transient transformation was still observed (Figure 3a).

Acetosyringone (AS), a molecule derived from wounded plants, is used by A. tumefaciens as a chemo-attractant to initiate cell adhesion (Binns and Thomashow, 1988). AS is added during the culturing of bacterial cells to increase virulence and, consequently, the efficiency of gene transfer can be improved (Sheikholeslam and Weeks, 1987; Sunilkumar et al. 1999). In our work, there were no significant differences observed between the different AS concentrations that were evaluated (Figure 4b). However, there was no homogenous transient transformation through the whole leaf area observed when AS was not supplied. This absolute AS-dependency has been also observed in Arabidopsis thaliana (Sheikholeslam and Weeks, 1987) and in C. annuum (Kim et al. 2001b), where AS was one of the essential components for pepper transformation.

The co-cultivation was developed for one, two or three days at two temperatures, 20 or $28^{\circ} \mathrm{C}$, and the best results were obtained when the co-cultivation proceeded for two days at $28^{\circ} \mathrm{C}$ (Table 1). The transformation efficiency was reduced when the co-cultivation occurred for three days, and no results were obtained when the co-cultivation was executed for one-day at $20^{\circ} \mathrm{C}$. Similar results were reported with $C$. annuum by $\mathrm{Li}$ et al. (2003) who observed that a cocultivation period of two days was optimal for the transformation of pepper cotyledons and hypocotyls, but a longer $(4,5,7$ days) co-cultivation period resulted in the necrosis of explants, which impeded shoot regeneration. In addition, in Citrus paradisi the highest number of $\mathrm{GUS}^{+}$ shoots and segments with $\mathrm{GUS}^{+}$shoots were obtained with a two-day co-cultivation period (Costa et al. 2002).

In order to control the hypersensitive response of the Habanero pepper leaf explants, induced by co-cultivation with A. tumefaciens, the effect of explant pre-cultivation with MS medium, without growth regulators was tested, using the best conditions from the co-cultivation experiments ( 2 days in the dark, on a shaker at $200 \mathrm{rpm}$ and at $28^{\circ} \mathrm{C}$ ). The one-hour pre-cultivation produced an almost $50 \%$ increment of change in the frequency of the GUS positive leaf explants for all of the constructs (Table 1). However, an extension of the pre-cultivation period $(6,12$ and $24 \mathrm{hrs}$ ) did not result in a significant change of the transient transformation (Figure $4 \mathrm{c}$ ). In the groundnut

(a)

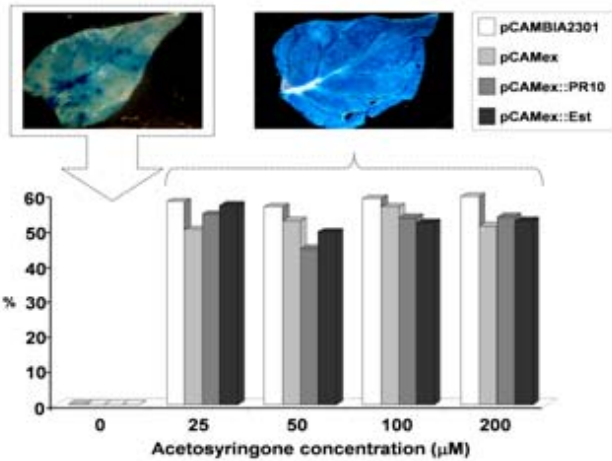

(b)

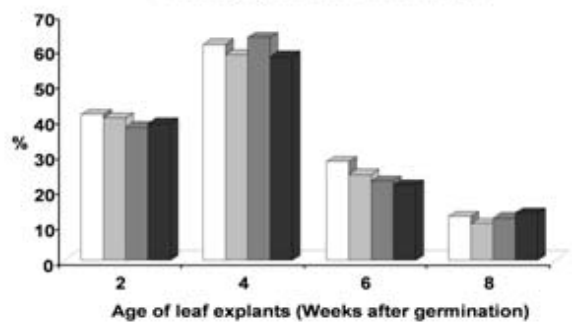

(c)

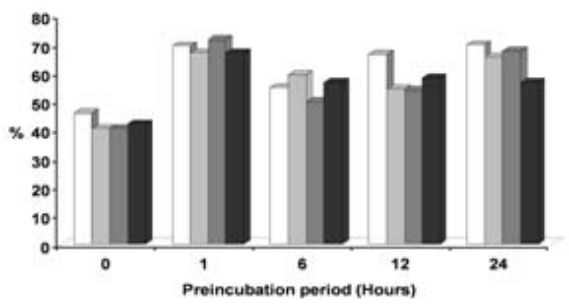

Figure 4. The factors affecting the efficiency of Capsicum chinense genetic transformation. The effect of different factors on the transformation efficiency was analyzed. (a) The leaf explants from four-week-old plantlets were co-cultivated with the $A$. tumefaciens strain that was previously cultivated in the presence of different concentrations of acetosyringone, as described. (b) The leaf explants from the pepper plantlets with different ages were transformed under the optimal conditions described in the text. (c) The leaf explants from four-week-old plantlets were pre-incubated in MS medium for several periods before co-cultivation. 
(Arachis hypogaea), the transformation efficiency of explants was higher when compared to those transformants that were obtained without pre-cultivation (Venkatachalam et al. 1998). Li et al. (2003) believed that the pepper explants, when preconditioned for a relatively long time, could not be infected well by A. tumefaciens, but that the preconditioning promoted the transformation of pepper explants. Over two decades, several studies have presented evidence for the existence of a "window of competence"; a time during which the cells are susceptible to Agrobacterium transformation, although the basis for this promotion of transformation by a pre-culturing of the explants has not yet been completely established. It has been proposed that the plant cells undergo a physiological adaptation to become competent for transformation during the pre-conditioning step (Sunilkumar et al. 1999; Costa et al. 2002). In addition, several authors have suggested that the pre-cultivation step has served to reduce plant-stress (Venkatachalam et al. 1998; Li et al. 2003).

The best results were obtained when the different factors evaluated were combined, and this produced an efficient protocol for the transient transformation of the Habanero pepper leaf explants. The most efficient protocol includes a $1 \mathrm{hr}$ pre-incubation in MS medium without growth regulators, followed by a combination of the three transformation methods previously evaluated, addition of $100 \mu \mathrm{M}$ AS to the YEB medium during bacterial culturing, and co-cultivation for 2 days in MS sterile liquid medium without growth regulators, in the dark and on a shaker adjusted to $200 \mathrm{rpm}$ at $28^{\circ} \mathrm{C}$.

We evaluated the expression of transgenes in the leaf explants that were transformed under these conditions. By means of RT-PCR assays, high levels of GUS transcripts were detected in the leaves transformed either with empty vectors or with PR10 and esterase genes (Figure 5a); as expected, GUS transcripts were not detected in the untransformed leaves (Figure 5a, lane 1). The transcripts for the PR10 and esterase genes were also detected in the transformed leaves (Figure 5b); however, both of the genes were also expressed, at lower levels, in the leaves transformed with the empty vectors (Figure 5b, lanes 3 and 5). Furthermore, lower levels of PR10 were present in the untransformed controls (Figure $5 b$, lane 2). As a member of the pathogenesis-related proteins, PR10 may be expressed as a result of both biotic and abiotic stresses. Esterase is not classified as a PR-family member, but it is a hydrolase that functions in the defence against pathogens ( Kim et al. 2001a). Thus, it is possible that these particular genes are expressed as a result of the transformation process itself, and that they are not the best examples to evaluate when determining the efficiency of genetic transformation. Nevertheless, as the results of GUS gene expression are clear, it is perfectly possible that the transformation procedure resulted in the over-expression of PR10 and esterase genes, in addition to their basal expression.
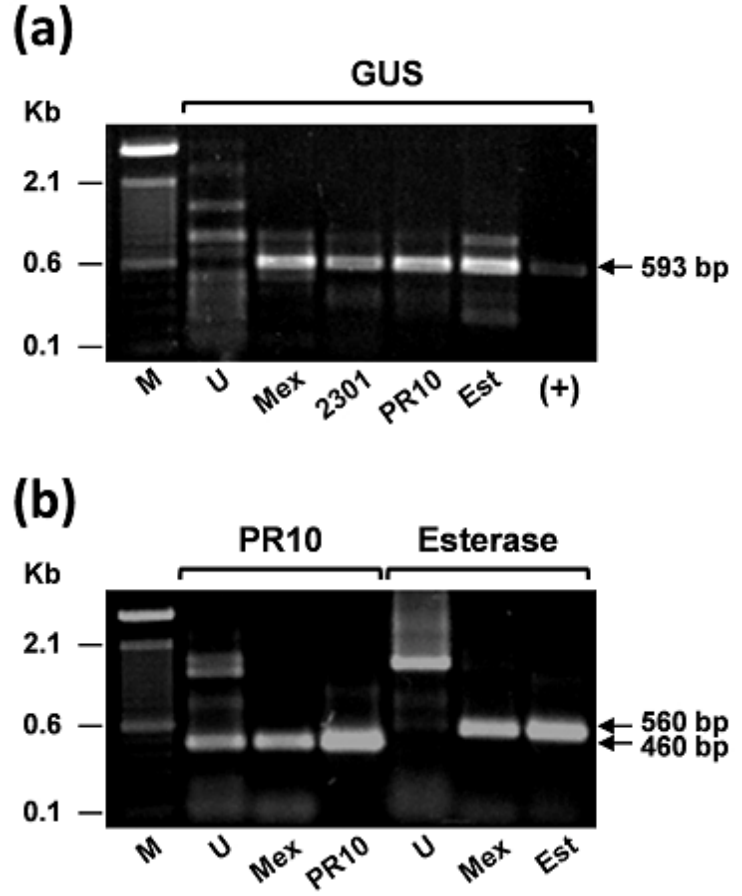

Figure 5. The detection of transgene transcripts in the transformed pepper leaves. Two micrograms of total RNA was extracted from transformed leaves and was reverse transcribed and PCR amplified with gene-specific primers. Two-microlitre aliquots of each RT-PCR product were fractionated by agarose gel electrophoresis and stained with $1 \mu \mathrm{g} \cdot \mathrm{mL}^{-1}$ ethidium bromide. (a) RT-PCR amplification of the GUS reporter transcript; (b) RTPCR amplification of the PR10 and esterase transcripts. M: $1 \mathrm{~Kb}$ DNA ladder (Invitrogen); U: untransformed leaves; Mex: empty pCAMex binary vector; 2301: empty pCAMBIA2301 binary vector; PR10: pCAMex::PR10 construct; Est: pCAMex::Esterase construct; (+) symbol: PCR positive control using pCAMBIA2301 binary vector as template.

Over the past five years, remarkable progress has been made in the development and understanding of the $A$. tumefaciens infection and transformation processes. The literature reviewed has provided strong evidence that there is a high recalcitrance of the peppers to the Agrobacteriummediated transformation, and to cell culture in vitro. As a consequence, there are no standard protocols that can be used between the different species, even within the Genus Capsicum. Researchers around the world use heterologous systems to express the pepper genes in order to study their biological functions (Kim et al. 2004). In the present study, a good system for the transient transformation of Capsicum chinense, the hottest habanero pepper worldwide (CantoFlick et al. 2008), has been established. This optimized protocol can thus be used to study pepper gene functions in a homologous system.

\section{ACKNOWLEDGMENTS}

GFAO and YENU gratefully acknowledge Consejo Nacional de Ciencia y Tecnología for the scholarships 56153 and 172927 , respectively. 


\section{REFERENCES}

ALWEN, Anna; BENITO MORENO, Rosa María; VICENTE, Oscar and HEBERLE-BORS, Erwin. Plant endogenous $\beta$-glucuronidase activity: how to avoid interference with the use of the $E$. coli $\beta$-glucuronidase as a reporter gene in transgenic plants. Transgenic Research, March 1992, vol. 1, no. 2, p. 63-70.

BINNS, A.N. and THOMASHOW, M.F. Cell biology of agrobacterium infection and transformation of plants. Annual Review of Microbiology, October 1988, vol. 42, p. 575-606.

CANTO-FLICK, Adriana; BALAM-UC, Eduardo; BELLO-BELLO, Jericó Jabin; LECONA-GUZMÁN, Carlos; SOLÍS-MARROQUÍN Daniela; AVILÉS-VIÑAS, Susana; GÓMEZ-UC, Eunice; LÓPEZ-PUC, Guadalupe; SANTANA-BUZZY, Nancy and IGLESIAS-ANDREU, Lourdes Georgina. Capsaicinoids content in habanero pepper (Capsicum chinense Jacq.): Hottest known cultivars. HortScience, August 2008, vol. 43, no. 5, p. 1344-1349.

COSTA, M.G.C.; OTONI, W.C. and MOORE, G.A. An evaluation of factors affecting the efficiency of Agrobacterium-mediated transformation of Citrus paradisi (Macf.) and production of transgenic plants containing carotenoid biosynthetic genes. Plant Cell Reports, November 2002, vol. 21, no. 4, p. 365-373.

FISCHER, Rainer; VAQUERO-MARTIN, Carmen; SACK, Markus; DROSSARD, Jürgen; EMANS, Neil and COMMANDEUR, Ulrich. Towards molecular farming in the future: transient protein expression in plants. Biotechnology and Applied Biochemistry, October 1999, vol. 30, part 2, p. 113-116.

GLEAVE, Andrew P. A versatile binary vector system with a T-DNA organizational structure conducive to efficient integration of cloned DNA into the plant genome. Plant Molecular Biology, December 1992, vol. 20, no. 6, p. 12031207.

HONG, Jong-Pil and KIM, Woo Taek. Isolation and functional characterization of the Ca-DREBLP1 gene encoding a dehydration-responsive element binding-factorlike protein 1 in hot pepper (Capsicum annuum L. cv. Pukang). Planta, April 2005, vol. 220, no. 6, p. 875-888.

HONG, J.H. and HWANG, B.K. Promoter activation of pepper class II basic chitinase gene, CAChi2, and enhanced bacterial disease resistance and osmotic stress tolerance in the CAChi2-overexpressing Arabidopsis. Planta, February 2006, vol. 223, no. 3, p. 433-448.

KAPILA, Jyoti; DE RYCKE, Riet; VAN MONTAGU, Marc and ANGENON, Geert. An Agrobacterium-mediated transient gene expression system for intact leaves. Plant Science, January 1997, vol. 122, no. 1, p. 101-108.
KIM, Young Jin; HWANG, Byung Kook and PARK, Kuen Woo. Expression of age-related resistance in pepper plants infected with Phytophthora capsici. Plant Disease, September 1989, vol. 73, no. 9, p. 745-747.

KIM, Sihyun; KIM, Seong-Ryong; AN, Chung Sun; HONG, Young-Nam and LEE, Kwang-Woong. Constitutive expression of rice MADS box gene using seed explants in hot pepper (Capsicum annuum L.). Molecules and Cells, October 2001b, vol. 12, no. 2, p. 221-226.

KIM, Young Soon; LEE, Hyun Hwa; KO, Moon Kyung; SONG, Chae Eun; BAE, Cheol-Yong; LEE, Yong Hwan and $\mathrm{OH}$, Boung-Jun. Inhibition of fungal appressorium formation by pepper (Capsicum annuum) esterase. Molecular Plant Microbe Interactions, January 2001a, vol. 14 , no. 1 , p. $80-85$.

KIM, Sang Hee; HONG, Jeum Kyu; LEE, Sung Chul; SOHN, Kee Hoon; JUNG, Ho Won and HWANG, Byung Kook. CAZFP1, Cys2/His2-type zinc-finger transcription factor gene functions as a pathogen-induced early-defense gene in Capsicum annuum. Plant Molecular Biology, August 2004, vol. 55, no. 6, p. 883-904.

LEE, Y.H.; KIM, H.S.; KIM, J.Y.; JUNG, M.; PARK, Y.S.; LEE, J.S.; CHOI, S.H.; HER, N.H.; LEE, J.H.; HYUNG, N.I.; LEE, C.H.; YANG, S.G. and HARN, C.H. A new selection method for pepper transformation: callusmediated shoot formation. Plant Cell Reports, August 2004, vol. 23, no. 1-2, p. 50-58.

LI, D.; ZHAO, K.; XIE, B.; ZHANG, B. and LUO, K. Establishment of a highly efficient transformation system for pepper (Capsicum annuum L.). Plant Cell Reports, April 2003, vol. 21, no. 8, p. 785-788.

MANOHARAN, M.; SREE VIDYA, C.S. and LAKSHMI SITA, G. Agrobacterium-mediated genetic transformation in hot chilli (Capsicum annuum L. var. Pusa jwala). Plant Science, January 1998, vol. 131, no. 1, p. 77-83.

MURASHIGE, Toshio and SKOOG, Folke. A revised medium for rapid growth and bio assays with tobacco tissue cultures. Physiologia Plantarum, July 1962, vol. 15, no. 3, p. 473-497.

NIANIOU, I.; KARAVANGELI, M.; ZAMBOUNIS, A. and TSAFTARIS, A. Development of pepper transgenic plants via Agrobacterium and biolistic transformation. In: Acta Horticulturae 579 (ISSH), II Balkan Symposium on Vegetables and Potatoes, Thessaloniki, Greece, May 2002, p. 83-87.

OCHOA-ALEJO, Neftali and RAMIREZ-MALAGON, Rafael. In vitro chili pepper biotechnology. In vitro Cellular \& Developmental Biology-Plant, November 2001, vol. 37, no. 6, p. 701-729. 
PARK, Chang-Jin; SHIN, Yun-Chul; LEE, Boo-Ja; KIM, Ki-Jeong; KIM, Jeong-Kook and PAEK, Kyung-Hee. A hot pepper gene encoding WRKY transcription factor is induced during hypersensitive response to tobacco mosaic virus and Xanthomonas campestris. Planta, January 2006, vol. 223 , no. 2 , p. 168-179.

PLEGT, Leon and BINO, Raoul J. $\beta$-glucuronidase activity during development of the male gametophyte from transgenic and non-transgenic plants. Molecular and General Genetics, April 1989, vol. 216, no. 2-3, p. 321327.

SANTANA-BUZZY, Nancy; CANTO-FLICK, Adriana; BARAHONA-PÉREZ, Felipe; MONTALVO-PENICHE, María del Carmen; ZAPATA-CASTILLO, Patricia Yolanda; SOLÍS-RUÍZ, Anabel; ZALDIVAR-COLLÍ, Amílcar; GUTIERREZ-ALONSO, Omar and MIRANDAHAM, María de Lourdes. Regeneration of habanero pepper (Capsicum chinense Jacq.) via organogenesis. HortScience, October 2005, vol. 40, no. 6, p. 1829-1831.

SAROWAR, Sujon; KIM, Young Jin; KIM, Eui Nam; KIM, Ki Deok; CHOI, Jun Young; HYUNG, Nam In and SHIN, Jeon Sheop. Constitutive expression of two pathogenesis-related genes in tomato plants enhanced resistance to oomycete pathogen Phytophthora capsici. Plant Cell Tissue and Organ Culture, July 2006, vol. 86, no. 1, p. 7-14.

SHEIKHOLESLAM, Shahla N. and WEEKS, Donald P. Acetosyringone promotes high efficiency transformation of Arabidopsis thaliana explants by Agrobacterium tumefaciens. Plant Molecular Biology, July 1987, vol. 8, no. 4, p. 291-298.

SHIVEGOWDA, S.T.; MYTHILI, J.B.; ANAND, L.; SAIPRASAD, G.V.S.; GOWDA, R. and GOWDA, T.K.S. In vitro regeneration and transformation in chilli pepper (Capsicum annuum L.). Journal of Horticultural Science and Biotechnology, September 2002, vol. 77, no. 5, p. 629634.

SUDAN, Charu; PRAKASH, Shiva; BHOMKAR, Prasanna; JAIN, Shalu and BHALLA-SARIN, Neera. Ubiquitous presence of $\beta$-glucuronidase (GUS) in plants and its regulation in some model plants. Planta, September 2006, vol. 224 , no. 4 , p. 853-864.

SUNILKUMAR, G.; VIJAYACHANDRA, K. and VELUTHAMBI, K. Preincubation of cut tobacco leaf explants promotes Agrobacterium-mediated transformation by increasing vir gene induction. Plant Science, February 1999, vol. 141, no. 1, p. 51-58.

VAN DER HOORN, Reiner A.L; LAURENT, Franck; ROTH, Ronelle and DE WIT, Pierre J.G.M. Agroinfiltration is a versatile tool that facilitates comparative analyses of Avr9/Cf-9-induced and Avr4/Cf-4- induced necrosis. Molecular Plant Microbe Interactions, April 2000, vol. 13, no. 4, p. 439-446.

VENKATACHALAM, Perumal; GEETHA, Natesan; JAYABALAN, Narayanasamipillai; SITA, Saravanababu, and SITA, Lakshmi. Agrobacterium-mediated genetic transformation of groundnut (Arachis hypogaea L.): An assessment of factors affecting regeneration of transgenic plants. Journal of Plant Research, December 1998, vol. 111, no. 4, p. 565-572.

ZALDIVAR-CRUZ, J.M.; BALLINA-GÓMEZ, H.; GUERRERO-RODRIGUEZ, C.; AVILÉS-BERZUNZA, E. and GODOY-HERNÁNDEZ, G.C. Agrobacteriummediated transient transformation of annatto (Bixa orellana L.) hypocotyls with the GUS reporter gene. Plant Cell Tissue and Organ Culture, June 2003, vol. 73, no. 3, p. 281-284.

ZAPATA-CASTILLO, Patricia Yolanda; CANTO-FLICK, Adriana; LÓPEZ-PUC, Guadalupe; SOLÍS-RUIZ, Anabel; BARAHONA-PÉREZ, Felipe and SANTANA-BUZZY, Nancy. Somatic embryogenesis in habanero pepper (C. chinense Jacq.) from cell suspensions. Hortscience, April 2007, vol. 42, no. 2, p. 329-333.

ZAR, Jerrold H. Biostatistical Analysis. Englewood Cliffs, N.J., Prentice Hall Inc., 1999. 663 p. ISBN: 0-13-081542$\mathrm{X}$. 